\title{
Evaluation Techniques for Traffic Safety of Operating Highway Tunnels
}

\author{
HongboWU \\ Research Institute of Highway, MOT, Beijing 100088, China
}

\begin{abstract}
With the consideration of frequent occurrence of traffic accidents on operating highway tunnels, the advancement of safety evaluation for highway tunnels in domestic and abroad are systematically summarized. Through the comprehensive analysis of infrastructure factors influencing on traffic safety of highway tunnels, safety checklists focusing on tunnel horizontal and vertical alignment, tunnel portal situation, pavement condition, ventilation and lighting facilities, traffic safety facilities are provided in qualitatively evaluating operating highway tunnels. Based on the concept of risk, risk assessment indices oriented in infrastructure factors, environmental factors and management factors for operation safety of expressway tunnels and standard highway tunnels are put forward. Quantitative evaluation methods based on indices architecture and the corresponding classification criteria for operation safety risk of tunnels are developed.
\end{abstract}

\section{Preface}

In recent years, with the development of national economy and the increasing demand of production and life, the highway transportation in China has developed rapidly, and the construction of highway tunnels has also made great achievements. By 2016, China had built 15,181 road tunnels with a total length of $14,039.7$ kilometers, including 815 extra-long tunnels with 3,622.7 kilometers and 3,520 long tunnels with 6,045.5 kilometers. The tunnel belongs to the road section with abrupt change of road environment. The driver needs to deal with a large amount of information in the process of vehicle driving, which is easy to cause operational errors, resulting in the tunnel becoming a section with frequent traffic accidents. As an important means to prevent traffic accidents and reduce the severity of accidents, safety evaluation has been widely used in foreign countries. Therefore, combined with the relevant research results domestic and abroad, through the analysis of the factors affecting the safety of highway tunnel operation, the corresponding safety checklist is prepared, and the quantitative safety assessment methods based on risk assessment are proposed respectively for highway and standard highway tunnels, in order to provide technical support for the safety assessment of highway tunnels in service.

\section{Analysis of research status domestic and abroad}

In the world, tunnel safety has always been very concerned. In particular, European countries began to pay attention to the safety of tunnel operation after major fire accidents in Mont Blanc tunnel and Taun tunnel. According to the requirements of "Minimum requirements for tunnel safety in the trans European road network Directive 2004 / 54 / EC of the European Conference / Council of 29 April 2004", it is necessary to carry out safety assessment on the tunnel and set up a special organization eurotest to check and evaluate the risk degree and safety of the existing road tunnel in Europe. Generally speaking, the technology of highway tunnel safety evaluation in European countries has developed earlier and more mature, and the evaluation method is mainly the combination of quantitative and qualitative. But there are also some shortcomings, such as the imperfect evaluation index system, the less consideration of the impact on human behavior and organizational structure, and the weak operability.

The research on the safety evaluation of highway tunnels started late in China. At present, the research mainly focuses on the safety evaluation index system and evaluation methods of tunnel operation or the advanced methods and technologies of the European Union, applying the concepts of risk potential and safety potential. The Specifications for Highway Safety Audit (JTG B05-2015), which was officially implemented in April 2016, only made general regulations on the safety evaluation contents of the existing highway tunnels from the aspects of highway geometry, sight distance, pavement anti-sliding ability, cross section, electromechanical facilities, safety facilities, etc. The existing research results and industry norms are relatively shallow to the special safety evaluation of highway tunnels in service, and lack of detailed evaluation index system and corresponding qualitative and quantitative

\footnotetext{
*Corresponding author: 345905760@qq.com
} 
evaluation methods, which is difficult to meet the safety evaluation requirements of a single tunnel.

\section{Evaluation method based on safety checklist}

According to the basic principles of safety engineering, combined with the relevant research results domestic and abroad and the summary and refinement of some typical road tunnel accidents, the safety checklist is a list of

Table 1. Safety checklists for operating highway tunnel

\begin{tabular}{|c|c|c|}
\hline Evaluation content & Evaluation means & $\begin{array}{l}\text { Evaluation } \\
\text { conclusion }\end{array}$ \\
\hline \multicolumn{3}{|l|}{1 horizontal alignment } \\
\hline $\begin{array}{l}\text { Is horizontal curve set in the tunnel? If it has to be set, is the flat curve } \\
\text { radius without superelevation adopted and meets the requirements of } \\
\text { stopping sight distance? }\end{array}$ & $\begin{array}{l}\text { Evaluation according to } \\
\text { design documents }\end{array}$ & \\
\hline $\begin{array}{l}\text { Is the exit direction of long and extra long tunnels connected with } \\
\text { small radius horizontal curve? }\end{array}$ & $\begin{array}{l}\text { Evaluation according to } \\
\text { design documents }\end{array}$ & \\
\hline \multicolumn{3}{|l|}{2 vertical alignment } \\
\hline $\begin{array}{l}\text { Does the longitudinal slope of the tunnel consider traffic safety, } \\
\text { operation ventilation scale and drainage requirements? Is it not less } \\
\text { than } 0.3 \% \text { and not more than } 3 \% \text { ? }\end{array}$ & $\begin{array}{l}\text { Evaluation according to } \\
\text { design documents }\end{array}$ & \\
\hline Are there too many slope change points in the tunnel? & $\begin{array}{l}\text { Evaluation according to } \\
\text { design documents }\end{array}$ & \\
\hline \multicolumn{3}{|c|}{3 horizontal and vertical alignment of portal section } \\
\hline $\begin{array}{l}\text { Is the horizontal and vertical alignment consistent within the range of } \\
3 \mathrm{~S} \text { design speed stroke length inside and outside the tunnel portal? }\end{array}$ & $\begin{array}{l}\text { Evaluation according to } \\
\text { design documents }\end{array}$ & \\
\hline $\begin{array}{l}\text { Is the tunnel entrance located near the slope change point of convex } \\
\text { vertical curve? }\end{array}$ & $\begin{array}{l}\text { Evaluation according to } \\
\text { design documents }\end{array}$ & \\
\hline $\begin{array}{l}\text { Is the tunnel portal located in the section with long and steep downhill } \\
\text { and small radius curve? }\end{array}$ & $\begin{array}{l}\text { Evaluation according to } \\
\text { design documents }\end{array}$ & \\
\hline $\begin{array}{c}\text { Is there a certain length of transition between the tunnel and the } \\
\text { wiring outside the tunnel? }\end{array}$ & $\begin{array}{l}\text { According to the design } \\
\text { documents and site survey } \\
\text { evaluation. }\end{array}$ & \\
\hline $\begin{array}{l}\text { Are emergency parking strips provided in long and extra long } \\
\text { tunnels? Does the width of the emergency stop belt meet the } \\
\text { requirements of safe parking for large trucks? }\end{array}$ & $\begin{array}{l}\text { According to the design } \\
\text { documents and site survey } \\
\text { evaluation. }\end{array}$ & \\
\hline \multicolumn{3}{|l|}{4 road surface } \\
\hline Does the tunnel pavement have good skid resistance? & $\begin{array}{l}\text { According to the field test } \\
\text { evaluation. }\end{array}$ & \\
\hline $\begin{array}{l}\text { When cement concrete is used in the tunnel and asphalt pavement is } \\
\text { used outside the tunnel, is there a certain length of transition section? }\end{array}$ & $\begin{array}{l}\text { According to the site survey } \\
\text { evaluation }\end{array}$ & \\
\hline $\begin{array}{c}\text { Is the long and extra long tunnel equipped with color pavement } \\
\text { within } 50 \mathrm{~m} \text { of the entrance and exit? }\end{array}$ & $\begin{array}{l}\text { According to site survey and } \\
\text { evaluation. }\end{array}$ & \\
\hline $\begin{array}{l}\text { Will the tunnel pavement return to moisture under adverse weather } \\
\text { conditions? }\end{array}$ & $\begin{array}{l}\text { According to site survey and } \\
\text { evaluation. }\end{array}$ & \\
\hline \multicolumn{3}{|l|}{5 ventilation facilities } \\
\hline $\begin{array}{l}\text { Does the tunnel ventilation design meet the requirements of current } \\
\text { specifications? }\end{array}$ & $\begin{array}{l}\text { Evaluation according to } \\
\text { design documents. }\end{array}$ & \\
\hline $\begin{array}{l}\text { Does the tunnel ventilation system have the ventilation control } \\
\text { function under normal and fire conditions? }\end{array}$ & $\begin{array}{l}\text { Evaluation according to } \\
\text { design documents. }\end{array}$ & \\
\hline Is ventilation good? Is good visibility guaranteed in the tunnel? & $\begin{array}{l}\text { According to site survey and } \\
\text { evaluation. }\end{array}$ & \\
\hline Is the ventilation equipment capable of resisting high temperature? & $\begin{array}{l}\text { Evaluation according to } \\
\text { design documents. }\end{array}$ & \\
\hline Can the fan run in reverse? & $\begin{array}{l}\text { According to field test } \\
\text { evaluation. }\end{array}$ & \\
\hline \multicolumn{3}{|l|}{6 lighting facilities } \\
\hline
\end{tabular}




\begin{tabular}{|c|c|}
\hline $\begin{array}{l}\text { Does the tunnel lighting design meet the requirements of current } \\
\text { specifications? }\end{array}$ & $\begin{array}{l}\text { Evaluation according to } \\
\text { design documents. }\end{array}$ \\
\hline Is the tunnel open normally? Is there emergency lighting? & $\begin{array}{l}\text { According to site survey and } \\
\text { evaluation. }\end{array}$ \\
\hline $\begin{array}{c}\text { Can power supply be ensured in case of partial failure? Is there a } \\
\text { continuous power system UPS? }\end{array}$ & $\begin{array}{l}\text { According to site survey and } \\
\text { evaluation. }\end{array}$ \\
\hline $\begin{array}{l}\text { Is there an obvious "black and white hole" effect at the tunnel } \\
\text { entrance? }\end{array}$ & $\begin{array}{l}\text { According to site survey and } \\
\text { evaluation. }\end{array}$ \\
\hline Whether the lighting fixtures are clean? & $\begin{array}{l}\text { According to site survey and } \\
\text { evaluation. }\end{array}$ \\
\hline \multicolumn{2}{|l|}{7 traffic safety facilities } \\
\hline $\begin{array}{l}\text { Are tunnel signs, speed limit signs and no overtaking signs set before } \\
\text { the tunnel entrance? }\end{array}$ & $\begin{array}{l}\text { According to site survey and } \\
\text { evaluation. }\end{array}$ \\
\hline $\begin{array}{l}\text { When the tunnel is long, the traffic volume is large and located in the } \\
\text { uphill road section, is lane indication sign set in front of the tunnel } \\
\text { entrance? }\end{array}$ & $\begin{array}{l}\text { According to site survey and } \\
\text { evaluation. }\end{array}$ \\
\hline $\begin{array}{l}\text { When the radius of horizontal curve in the tunnel is small, is there a } \\
\text { linear guide sign or active luminous contour sign? }\end{array}$ & $\begin{array}{l}\text { According to the design } \\
\text { documents and site survey } \\
\text { evaluation. }\end{array}$ \\
\hline Is the end wall of tunnel portal marked with facade mark? & $\begin{array}{l}\text { According to site survey and } \\
\text { evaluation. }\end{array}$ \\
\hline $\begin{array}{l}\text { Is a zebra crossing in the direction of oblique traffic built in the hard } \\
\text { shoulder } 50 \mathrm{~m} \text { in front of the tunnel entrance? }\end{array}$ & $\begin{array}{l}\text { According to site survey and } \\
\text { evaluation. }\end{array}$ \\
\hline $\begin{array}{l}\text { Is lane change forbidden at the boundary of carriageway } 100 \mathrm{~m} \text { in } \\
\text { front of the tunnel entrance and } 50 \mathrm{~m} \text { behind the tunnel exit? }\end{array}$ & $\begin{array}{l}\text { According to site survey and } \\
\text { evaluation. }\end{array}$ \\
\hline $\begin{array}{l}\text { Is the subgrade guardrail gradually transited to the end of the tunnel } \\
\text { portal access road? }\end{array}$ & $\begin{array}{l}\text { According to site survey and } \\
\text { evaluation. }\end{array}$ \\
\hline $\begin{array}{l}\text { In order to alleviate the "black hole" and "white hole" effects at the } \\
\text { entrance and exit of the tunnel, are active light-emitting inducing } \\
\text { facilities set up to realize the smooth transition of light and shade } \\
\text { level inside and outside the tunnel? }\end{array}$ & $\begin{array}{l}\text { According to site survey and } \\
\text { evaluation. }\end{array}$ \\
\hline \multicolumn{2}{|c|}{8 fire fighting and rescue facilities } \\
\hline $\begin{array}{l}\text { Is the number of fire extinguishers in accordance with fire } \\
\text { regulations? }\end{array}$ & $\begin{array}{l}\text { According to site survey and } \\
\text { evaluation. }\end{array}$ \\
\hline Is the fire extinguisher in an open and fixed position and easy to use? & $\begin{array}{l}\text { According to site survey and } \\
\text { evaluation. }\end{array}$ \\
\hline $\begin{array}{l}\text { Is the fire extinguisher dated? Is it regularly inspected and } \\
\text { maintained? }\end{array}$ & $\begin{array}{l}\text { According to site survey and } \\
\text { evaluation. }\end{array}$ \\
\hline Does the fire hose and emergency broadcast system work normally? & $\begin{array}{l}\text { According to the field test } \\
\text { evaluation. }\end{array}$ \\
\hline Is the fire hydrant and fire pump adapter in good condition? & $\begin{array}{l}\text { According to field test } \\
\text { evaluation. }\end{array}$ \\
\hline $\begin{array}{l}\text { Is there a fire water reservoir? Is there any accumulation and garbage } \\
\text { in the pool? }\end{array}$ & $\begin{array}{l}\text { According to site survey and } \\
\text { evaluation. }\end{array}$ \\
\hline Is the emergency exit spacing reasonable? & $\begin{array}{l}\text { Evaluate according to the } \\
\text { design documents }\end{array}$ \\
\hline Is the emergency exit sign set? Is it clearly visible? & $\begin{array}{l}\text { According to site survey and } \\
\text { evaluation. }\end{array}$ \\
\hline $\begin{array}{l}\text { Is the escape way provided with good smoke and fire protection } \\
\text { function? }\end{array}$ & $\begin{array}{l}\text { According to site survey and } \\
\text { evaluation. }\end{array}$ \\
\hline Is there emergency lighting in the escape way? & $\begin{array}{l}\text { According to site survey and } \\
\text { evaluation. }\end{array}$ \\
\hline \multicolumn{2}{|l|}{9 monitoring facilities } \\
\hline Is there a tunnel monitoring center? & $\begin{array}{l}\text { According to site survey and } \\
\text { evaluation. }\end{array}$ \\
\hline Is the tunnel monitoring center manned 24 hours a day? & $\begin{array}{l}\text { According to on-site inquiry } \\
\text { and evaluation. }\end{array}$ \\
\hline Is vehicle detector installed? Is the vehicle detector intact? & $\begin{array}{l}\text { According to site survey and } \\
\text { evaluation. }\end{array}$ \\
\hline
\end{tabular}




\begin{tabular}{|c|c|}
\hline Can real-time monitoring of the whole tunnel be realized? & $\begin{array}{l}\text { According to site survey and } \\
\text { evaluation. }\end{array}$ \\
\hline $\begin{array}{c}\text { Does the camera and video monitoring control equipment work } \\
\text { normally? }\end{array}$ & $\begin{array}{l}\text { Pass the field test } \\
\text { evaluation。 }\end{array}$ \\
\hline Is variable information board installed? & $\begin{array}{l}\text { According to site survey and } \\
\text { evaluation. }\end{array}$ \\
\hline Is there a radio broadcast in the whole tunnel? & $\begin{array}{l}\text { According to site survey and } \\
\text { evaluation. }\end{array}$ \\
\hline $\begin{array}{c}\text { Is there an emergency phone? Are emergency telephone signs } \\
\text { complete? }\end{array}$ & $\begin{array}{l}\text { According to site survey and } \\
\text { evaluation. }\end{array}$ \\
\hline \multicolumn{2}{|l|}{10 other facilities } \\
\hline $\begin{array}{l}\text { Is the long and extra long tunnel provided with a connecting passage } \\
\text { at a suitable position outside the tunnel entrance to facilitate vehicle } \\
\text { turning around? }\end{array}$ & $\begin{array}{l}\text { According to site survey and } \\
\text { evaluation. }\end{array}$ \\
\hline $\begin{array}{c}\text { For the road section with more heavy vehicles, does the cover } \\
\text { strength of drainage side ditch and cable trench in the tunnel meet the } \\
\text { requirements of vehicle driving? }\end{array}$ & $\begin{array}{l}\text { Through the evaluation of } \\
\text { design documents. }\end{array}$ \\
\hline $\begin{array}{l}\text { When the tunnel exit is greatly affected by bad weather, such as heavy } \\
\text { fog and snowfall, have targeted measures been taken? }\end{array}$ & $\begin{array}{l}\text { According to site survey and } \\
\text { evaluation. }\end{array}$ \\
\hline
\end{tabular}

\section{Evaluation method based on risk assessment}

After many years of operation, some highway tunnels have some problems, such as the aging or defect of fire-fighting equipment, the failure of ventilation and lighting facilities to operate as required, the weak emergency rescue capacity, the inadequate management of dangerous goods transport vehicles, etc., which lead to a large potential safety hazard and traffic accidents. Therefore, in the process of tunnel operation, the concept of risk is introduced, the safety risk of tunnel operation is identified, and its qualitative and quantitative evaluation is carried out, which has attracted the attention of many researchers domestic and abroad, and qualitative and quantitative evaluation methods such as Delphi method, event tree method, checklist method, analytic hierarchy process, fuzzy comprehensive evaluation method are proposed.

\subsection{Safety risk assessment of expressway tunnel operation}

Because there are many risk factors that affect the safety of highway tunnel operation, some of them, such as driver and vehicle conditions, are difficult to quantify. In order to evaluate the safety risk of expressway tunnel operation accurately, it is necessary to extract the risk factors which are easy to quantitatively or qualitatively evaluate and have great influence on the safety risk of operation on the basis of safety risk identification, and then establish the corresponding risk assessment index system. Combined with the current situation of expressway tunnel operation safety in China and relevant research results domestic and abroad, the tunnel operation safety risk assessment index system as shown in Table 2. It is constructed from three aspects of facility factors, environmental factors and management factors.

Table 2. Risk assessment indices for operation safety of expressway tunnels

\begin{tabular}{|c|c|c|c|c|c|c|}
\hline \multirow[b]{2}{*}{ Factors } & \multirow[b]{2}{*}{$\begin{array}{l}\text { Evaluation } \\
\text { index }\end{array}$} & \multirow[b]{2}{*}{ Classification } & \multicolumn{2}{|c|}{ Basic score (Rij) } & \multirow[b]{2}{*}{$\begin{array}{c}\text { weight } \\
\text { coefficient }\left(\gamma_{\mathrm{ij}}\right)\end{array}$} & \multirow[b]{2}{*}{$\begin{array}{l}\text { Evaluation } \\
\text { score }\left(T_{i j}\right)\end{array}$} \\
\hline & & & $\begin{array}{l}\text { Range } \\
\text { of } \\
\text { values }\end{array}$ & Value & & \\
\hline \multirow{9}{*}{$\begin{array}{l}\text { Facility factor } \\
\qquad \mathrm{T}_{1}\end{array}$} & \multirow{4}{*}{$\begin{array}{c}\text { Tunnel length } \\
\mathrm{T}_{11}\end{array}$} & $\mathrm{~L}>3000 \mathrm{~m}$ & $75-100$ & \multirow{4}{*}{$\mathrm{R}_{11}$} & \multirow{4}{*}{$\gamma_{11}$} & \multirow{4}{*}{$\mathrm{T}_{11}=\gamma_{11} \times \mathrm{R}_{11}$} \\
\hline & & $1000 \mathrm{~m}<\mathrm{L} \leq 3000 \mathrm{~m}$ & $50-74$ & & & \\
\hline & & $500 \mathrm{~m}<\mathrm{L} \leq 1000 \mathrm{~m}$ & $25-49$ & & & \\
\hline & & $\mathrm{L} \leq 500 \mathrm{~m}$ & $0-24$ & & & \\
\hline & \multirow{4}{*}{$\begin{array}{c}\text { Horizontal } \\
\text { and vertical } \\
\text { alignment } \\
\text { combination } \\
\text { of tunnel } \\
\mathrm{T}_{12}\end{array}$} & $\begin{array}{l}\text { The combination of horizontal and } \\
\text { vertical alignment is poor, and there } \\
\text { is a serious potential safety hazard }\end{array}$ & $75-100$ & \multirow{4}{*}{$\mathrm{R}_{12}$} & \multirow{4}{*}{$\gamma_{12}$} & \multirow{4}{*}{$\mathrm{T}_{12}=\gamma_{12} \times \mathrm{R}_{12}$} \\
\hline & & $\begin{array}{c}\text { The combination of horizontal and } \\
\text { vertical alignment is unreasonable, } \\
\text { and there is obvious potential safety } \\
\text { hazard }\end{array}$ & $50-74$ & & & \\
\hline & & $\begin{array}{l}\text { Poor combination of horizontal and } \\
\text { vertical alignment has certain impact } \\
\text { on driving safety }\end{array}$ & $25-49$ & & & \\
\hline & & $\begin{array}{c}\text { Good combination of horizontal and } \\
\text { vertical alignment }\end{array}$ & $0-24$ & & & \\
\hline & Skid & $\mathrm{SFC}<0.3$ & $75-100$ & $\mathrm{R}_{13}$ & $\gamma_{13}$ & $\mathrm{~T}_{13}=\gamma_{13} \times \mathrm{R}_{13}$ \\
\hline
\end{tabular}




\begin{tabular}{|c|c|c|c|c|c|c|}
\hline & resistance of & $0.3 \leq \mathrm{SFC}<0.4$ & $50-74$ & & & \\
\hline & pavement $\mathrm{T}_{13}$ & $0.4 \leq \mathrm{SFC}<0.5$ & $25-49$ & & & \\
\hline & & $\mathrm{SFC} \geq 0.5$ & $0-24$ & & & \\
\hline & & $\begin{array}{c}\text { The tunnel section lacks } \\
\text { corresponding safety protection, } \\
\text { driving guidance and speed control } \\
\text { facilities }\end{array}$ & $75-100$ & & & \\
\hline & $\begin{array}{l}\text { Safety } \\
\text { facilities } \\
\mathrm{T}_{14}\end{array}$ & $\begin{array}{c}\text { The tunnel portal lacks necessary } \\
\text { safety protection and speed control } \\
\text { facilities }\end{array}$ & $50-74$ & $\mathrm{R}_{14}$ & $\gamma_{14}$ & $\mathrm{~T}_{14}=\gamma_{14} \times \mathrm{R}_{14}$ \\
\hline & & $\begin{array}{l}\text { Lack of necessary driving guidance } \\
\text { and prompt facilities in the tunnel }\end{array}$ & $25-49$ & & & \\
\hline & & $\begin{array}{l}\text { Perfect and reasonable traffic safety } \\
\text { facilities in tunnel section }\end{array}$ & $0-24$ & & & \\
\hline & & $\begin{array}{l}\text { The lighting in the tunnel is not } \\
\text { turned on }\end{array}$ & $75-100$ & & & \\
\hline & Tunnel & $\begin{array}{l}\text { The tunnel lighting is poor, and there } \\
\text { is obvious black and white hole } \\
\text { effect at the tunnel entrance }\end{array}$ & $50-74$ & & & \\
\hline & $\begin{array}{l}\text { lighting } \\
\mathrm{T}_{15}\end{array}$ & $\begin{array}{l}\text { The tunnel lighting is general, and } \\
\text { there are some light and shade } \\
\text { adaptation problems at the entrance } \\
\text { of the tunnel }\end{array}$ & $25-49$ & $\mathrm{R}_{15}$ & $\gamma_{15}$ & $\mathrm{~T}_{15}=\gamma_{15} \times \mathrm{R}_{15}$ \\
\hline & & Good tunnel lighting & $0-24$ & & & \\
\hline & & $\mathrm{D}>650 \mathrm{~m}$ & $75-100$ & & & \\
\hline & Emergency & $450 \mathrm{~m}<\mathrm{D} \leq 650 \mathrm{~m}$ & $50-74$ & $P_{.}$ & & $\mathrm{T}_{1}=\gamma \times \mathrm{P}$ \\
\hline & $\begin{array}{l}\text { exit distance } \\
\mathrm{T}_{16}\end{array}$ & $250 \mathrm{~m}<\mathrm{D} \leq 450 \mathrm{~m}$ & $25-49$ & $\mathrm{~K}_{16}$ & $\gamma_{16}$ & $1_{16}=\gamma_{16} \times \mathrm{K}_{16}$ \\
\hline & & $\mathrm{D} \leq 250 \mathrm{~m}$ & $0-24$ & & & \\
\hline & & $\begin{array}{l}\text { The monitoring facilities are not } \\
\text { perfect and most of them cannot be } \\
\text { used normally }\end{array}$ & $75-100$ & & & \\
\hline & $\begin{array}{l}\text { Monitoring } \\
\text { facilities }\end{array}$ & $\begin{array}{l}\text { The monitoring facilities are not } \\
\text { perfect and some of them cannot be } \\
\text { used normally }\end{array}$ & $50-74$ & $\mathrm{R}_{17}$ & $\gamma_{17}$ & $\mathrm{~T}_{17}=\gamma_{17} \times \mathrm{R}_{17}$ \\
\hline & & $\begin{array}{l}\text { Some monitoring facilities cannot be } \\
\text { used normally }\end{array}$ & $25-49$ & & & \\
\hline & & $\begin{array}{c}\text { Complete and reliable monitoring } \\
\text { facilities }\end{array}$ & $0-24$ & & & \\
\hline & Annual & AADT $>30000$ & $75-100$ & & & \\
\hline & average daily & $10000<\mathrm{AADT} \leq 30000$ & $50-74$ & & & \\
\hline & $\begin{array}{l}\text { traffic volume } \\
\text { of single }\end{array}$ & $4000<$ AADT $\leq 10000$ & $25-49$ & $\mathrm{R}_{21}$ & $\gamma_{21}$ & $\mathrm{~T}_{21}=\gamma_{21} \times \mathrm{R}_{21}$ \\
\hline & tunnel $\mathrm{T}_{21}$ & $\mathrm{AADT} \leq 4000$ & $0-24$ & & & \\
\hline environmental & & $\mathrm{HGV}>50 \%$ & $75-100$ & & & \\
\hline factor & Heavy truck & $30 \%<\mathrm{HGV} \leq 50 \%$ & $50-74$ & $P_{2}$ & & $\mathrm{~T}_{2}=\mu_{2} \times \mathrm{P}_{2}$ \\
\hline $\mathrm{T}_{2}$ & ratio & $10 \%<\mathrm{HGV} \leq 30 \%$ & $25-49$ & $\mathrm{R}_{22}$ & $\gamma_{22}$ & $\mathrm{I}_{22}=\gamma_{22} \times \mathrm{R}_{22}$ \\
\hline & & $\mathrm{HGV} \leq 10 \%$ & $0-24$ & & & \\
\hline & & Frequent bad weather & $75-100$ & & & \\
\hline & Climatic & More bad weather & $50-74$ & & & \\
\hline & factors & Less bad weather & $25-49$ & $\mathrm{R}_{23}$ & $\gamma_{23}$ & $\mathrm{~T}_{23}=\gamma_{23} \times \mathrm{R}_{23}$ \\
\hline & & Almost no bad weather & $0-24$ & & & \\
\hline & Accident rate & $\mathrm{CR}>0.50$ & $75-100$ & & & \\
\hline & per million & $0.30<\mathrm{CR} \leq 0.50$ & $50-74$ & & & \\
\hline & $\begin{array}{l}\text { vehicle } \\
\text { kil }\end{array}$ & $0.15<\mathrm{CR} \leq 0.30$ & $25-49$ & $\mathrm{R}_{31}$ & $\gamma_{31}$ & $\mathrm{~T}_{31}=\gamma_{31} \times \mathrm{R}_{31}$ \\
\hline & $\mathrm{T}_{31}$ & $\mathrm{CR} \leq 0.15$ & $0-24$ & & & \\
\hline & & $\mathrm{SL}>100 \mathrm{~km} / \mathrm{h}$ & $75-100$ & & & \\
\hline Management & Speed limit & $80 \mathrm{~km} / \mathrm{h}<\mathrm{SL} \leq 100 \mathrm{~km} / \mathrm{h}$ & $50-74$ & $\mathrm{R}_{32}$ & $\gamma_{32}$ & $T_{32}=\gamma_{32} \times R_{32}$ \\
\hline factors $T_{3}$ & $\mathrm{~T}_{32}$ & $60 \mathrm{~km} / \mathrm{h}<\mathrm{SL} \leq 80 \mathrm{~km} / \mathrm{h}$ & $25-49$ & $\mathrm{~K}_{32}$ & $\gamma_{32}$ & $1_{32}=\gamma_{32} \times \mathrm{K}_{32}$ \\
\hline & & $\mathrm{SL} \leq 60 \mathrm{~km} / \mathrm{h}$ & $0-24$ & & & \\
\hline & & ERT $>20 \mathrm{~min}$ & $75-100$ & & & \\
\hline & Emergency & $10<$ ERT $\leq 20 \mathrm{~min}$ & $50-74$ & $\mathrm{P}_{2}$ & & $\mathrm{~T}_{2}=\gamma_{23} \times \mathrm{P}_{3}$ \\
\hline & response time & $5<$ ERT $\leq 10 \mathrm{~min}$ & $25-49$ & $\mathrm{R}_{33}$ & $\gamma_{33}$ & $1_{33}=\gamma_{33} \times \mathrm{R}_{33}$ \\
\hline & & ERT $\leq 5 \mathrm{~min}$ & $0-24$ & & & \\
\hline
\end{tabular}




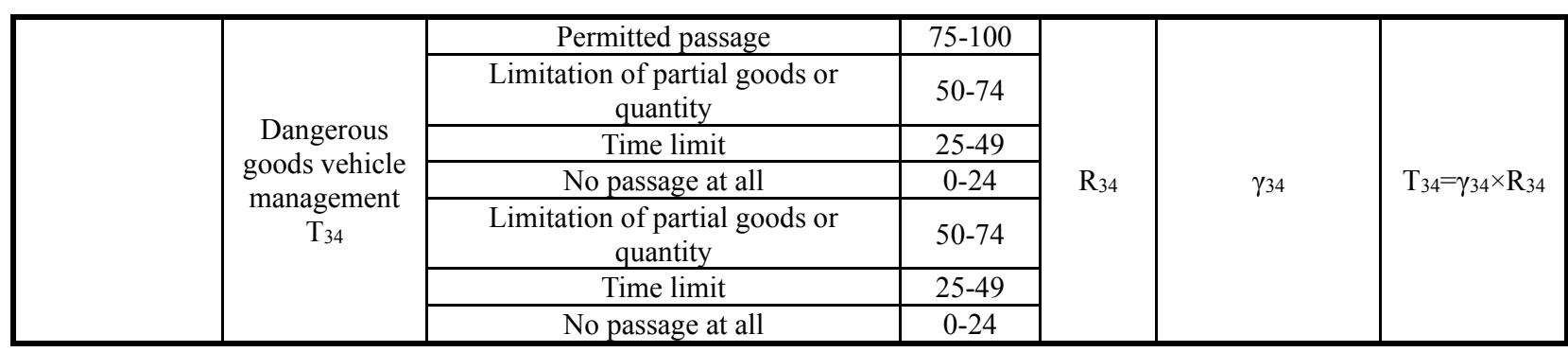

\subsection{Operation safety risk assessment of standard highway tunnel}

Since the overtaking tunnel or another tunnel can be used for traffic evacuation and escape in the event of an accident in the expressway tunnel, traffic organization and rescue escape will face greater problems in the event of an accident in the standard highway tunnel, therefore, it is necessary to evaluate the operation safety risk of the

Table 3. Risk assessment indices for operation safety of standard highway tunnels

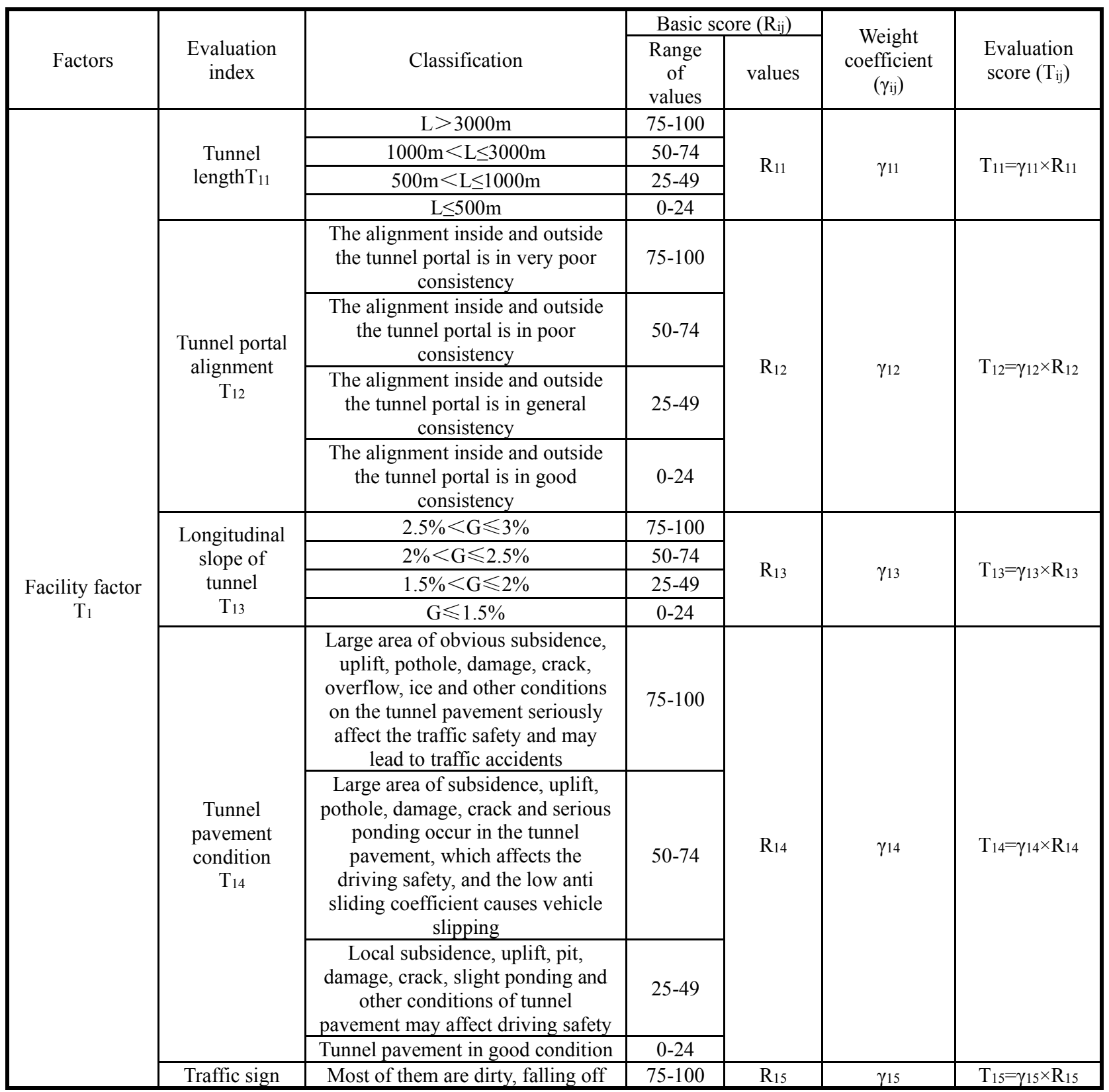

standard highway tunnel. Considering that compared with the expressway tunnel, the standard highway tunnel is poor in geometry, ventilation and safety management, on the basis of expressway tunnel operation safety risk evaluation index system, several evaluation indexes are added, and the evaluation index system of standard highway tunnel operation safety risk is proposed as shown in Table 3. 


\begin{tabular}{|c|c|c|c|c|c|c|}
\hline & $\begin{array}{l}\text { marking } \\
\mathrm{T}_{15}\end{array}$ & $\begin{array}{l}\text { and missing, which affects driving } \\
\text { safety }\end{array}$ & & & & \\
\hline & & $\begin{array}{l}\text { There are dirt, local falling off, } \\
\text { loss, etc., which affect traffic safety }\end{array}$ & $50-74$ & & & \\
\hline & & $\begin{array}{c}\text { Dirty, incomplete, not obstructing } \\
\text { traffic }\end{array}$ & $25-49$ & & & \\
\hline & & intact & $0-24$ & & & \\
\hline & & $\begin{array}{l}\text { There is no lighting lamp in the } \\
\text { tunnel or the lighting lamp is not } \\
\text { turned on }\end{array}$ & $75-100$ & & & \\
\hline & $\begin{array}{l}\text { Tunnel } \\
\text { lighting }\end{array}$ & $\begin{array}{l}\text { The tunnel lighting is poor, and } \\
\text { there is obvious "black and white } \\
\text { hole" effect at the tunnel entrance }\end{array}$ & $50-74$ & $\mathrm{R}_{16}$ & $\gamma_{16}$ & $\mathrm{~T}_{16}=\gamma_{16} \times \mathrm{R}_{16}$ \\
\hline & & $\begin{array}{l}\text { Tunnel lighting is general, and } \\
\text { there are some light and shade } \\
\text { adaptation problems at the entrance } \\
\text { of the tunnel }\end{array}$ & $25-49$ & & & \\
\hline & & Good tunnel lighting & $0-24$ & & & \\
\hline & & $\begin{array}{c}\text { There is no ventilation facilities in } \\
\text { the tunnel or the ventilation } \\
\text { facilities cannot be opened } \\
\text { normally }\end{array}$ & $75-100$ & & & \\
\hline & $\begin{array}{c}\text { Tunnel } \\
\text { ventilation } \\
\mathrm{T}_{17}\end{array}$ & $\begin{array}{c}\text { There are few ventilation facilities } \\
\text { in the tunnel or some ventilation } \\
\text { facilities are damaged }\end{array}$ & $50-74$ & $\mathrm{R}_{17}$ & $\gamma_{17}$ & $\mathrm{~T}_{17}=\gamma_{17} \times \mathrm{R}_{17}$ \\
\hline & & $\begin{array}{l}\text { Some ventilation facilities in the } \\
\text { tunnel are damaged }\end{array}$ & $25-49$ & & & \\
\hline & & $\begin{array}{l}\text { Ventilation facilities in the tunnel } \\
\text { can be opened normally }\end{array}$ & $0-24$ & & & \\
\hline & & $\begin{array}{l}\text { There is no fire alarm and fire } \\
\text { rescue facilities in the tunnel or the } \\
\text { facilities cannot be used normally }\end{array}$ & $75-100$ & & & \\
\hline & $\begin{array}{l}\text { Evacuation } \\
\text { and rescue } \\
\text { facilities }\end{array}$ & $\begin{array}{c}\text { There are only a few fire alarm and } \\
\text { fire rescue facilities in the tunnel or } \\
\text { some facilities cannot be used } \\
\text { normally }\end{array}$ & $50-74$ & $\mathrm{R}_{18}$ & $\gamma_{18}$ & $\mathrm{~T}_{18}=\gamma_{18} \times \mathrm{R}_{18}$ \\
\hline & $\mathrm{T}_{18}$ & $\begin{array}{l}\text { Some fire alarm and fire rescue } \\
\text { facilities in the tunnel cannot be } \\
\text { used normally }\end{array}$ & $25-49$ & & & \\
\hline & & $\begin{array}{l}\text { Necessary fire alarm and rescue } \\
\text { facilities shall be set in the tunnel }\end{array}$ & $0-24$ & & & \\
\hline & & $\begin{array}{l}\text { There is no monitoring facility in } \\
\text { the tunnel or the monitoring facility } \\
\text { cannot be used normally }\end{array}$ & $75-100$ & & & \\
\hline & $\begin{array}{l}\text { Monitoring } \\
\text { facilitiesT }_{19}\end{array}$ & $\begin{array}{l}\text { There are only a few monitoring } \\
\text { facilities in the tunnel or some of } \\
\text { them cannot be used normally }\end{array}$ & $50-74$ & $\mathrm{R}_{19}$ & $\gamma_{19}$ & $\mathrm{~T}_{19}=\gamma_{19} \times \mathrm{R}_{19}$ \\
\hline & & $\begin{array}{l}\text { Some monitoring facilities in the } \\
\text { tunnel cannot be used normally }\end{array}$ & $25-49$ & & & \\
\hline & & $\begin{array}{l}\text { The monitoring facilities in the } \\
\text { tunnel are relatively complete }\end{array}$ & $0-24$ & & & \\
\hline & & $\begin{array}{l}\text { AADT }>15000, \text { The situation of } \\
\text { mixed operation of locomotive and } \\
\text { non locomotive is serious }\end{array}$ & $75-100$ & & & \\
\hline Environmental & $\begin{array}{l}\text { Annual } \\
\text { average daily }\end{array}$ & $\begin{array}{c}6000<\text { AADT } \leq 15000, \text { The } \\
\text { situation of mixed operation of } \\
\text { locomotive and non locomotive is } \\
\text { relatively serious }\end{array}$ & $50-74$ & $\mathrm{R}_{21}$ & $\gamma_{21}$ & $\mathrm{~T}_{21}=\gamma_{21} \times \mathrm{R}_{21}$ \\
\hline $\begin{array}{c}\text { factors } \\
\mathrm{T}_{2}\end{array}$ & $\mathrm{~T}_{21}$ & $\begin{array}{l}2000<\text { AADT } \leq 6000, \text { There are } \\
\text { few cases of mixed operation of } \\
\text { locomotive and non locomotive }\end{array}$ & $25-49$ & & & \\
\hline & & $\begin{array}{l}\text { AADT } \leq 2000, \text { The situation of } \\
\text { mixed operation of locomotive and } \\
\text { non locomotive is very seldom }\end{array}$ & $0-24$ & & & \\
\hline & Heavy vehicle & $\mathrm{HGV}>50 \%$ & $75-100$ & $R_{2}$ & ברט & 20 \\
\hline & percentage & $30 \%<\mathrm{HGV} \leq 50 \%$ & $50-74$ & $1 \times 22$ & $\gamma_{22}$ & $122-\gamma$ \\
\hline
\end{tabular}




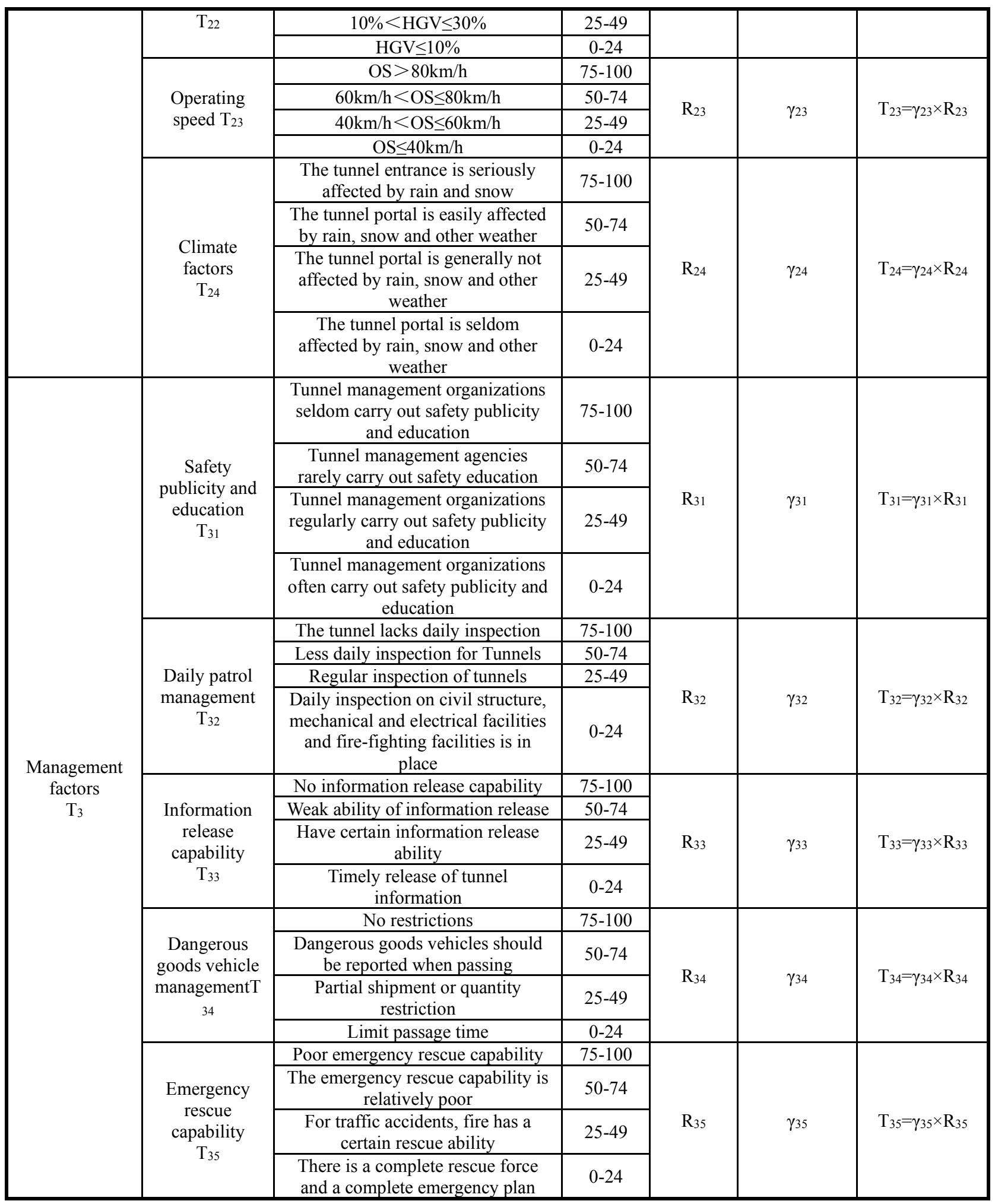

According to the risk assessment index system established in Table 2 and Table 3, the safety risk of tunnel operation is evaluated by the index system method. The safety risk of tunnel operation shall be determined according to formula (1) and (2).

$$
\begin{gathered}
R=\Sigma T_{i j} \\
T_{i j}=\gamma_{i j} \times R_{i j}
\end{gathered}
$$

Where: $T_{i j}$ - the evaluation score of the evaluation index, $i=1,2,3 ; j=1,2, \ldots \ldots n, n$ is the number of the corresponding class of evaluation index; $R_{i j}$-the basic score of the evaluation index. For the quantitative index, the value of the evaluation index can be obtained through design documents, field observation or field test, and the basic score can be calculated by linear interpolation method. For the qualitative index, it can be determined by the professional according to the engineering 
experience; $\gamma_{i j}$ - weight coefficient of each evaluation index, generally, it is determined by the method of "determining the value of weight by ranking the importance of evaluation indicators", and the calculation formula(3) is as follows:

$$
\gamma_{i j}=\frac{2 n-2 m+1}{n^{2}}
$$

Where: $n$ - number of evaluation index items; $m$ importance sequence number. $m \leq n$.

Through expert consultation and discussion, the importance ranking of safety risk assessment indicators for expressway and standard highway tunnel operation is determined, and the weight coefficient of safety risk assessment indicators for expressway tunnel operation is calculated by formula (3) as shown in Table 4.

Table 4. Classification criteria for operation safety risk of tunnel

\begin{tabular}{|c|c|c|}
\hline No & Evaluation indicators & $\begin{array}{c}\text { Weight } \\
\text { coefficient }\end{array}$ \\
\hline 1 & Tunnel length $\mathrm{T}_{11}$ & 0.14 \\
\hline 2 & $\begin{array}{c}\mathrm{T}_{12} \\
\text { Horizontal and vertical alignment combination of tunnel }\end{array}$ & 0.11 \\
\hline 3 & Skid resistance of pavement $\mathrm{T}_{13}$ & 0.06 \\
\hline 4 & Safety facilities $\mathrm{T}_{14}$ & 0.05 \\
\hline 5 & Tunnel lighting $\mathrm{T}_{15}$ & 0.08 \\
\hline 6 & Emergency exit distance $\mathrm{T}_{16}$ & 0.02 \\
\hline 7 & Monitoring facilities $\mathrm{T}_{17}$ & 0.03 \\
\hline 8 & Annual average daily traffic volume of single tunnel $\mathrm{T}_{21}$ & 0.13 \\
\hline 9 & Heavy truck ratio $\mathrm{T}_{22}$ & 0.09 \\
\hline 10 & Climatic factors $\mathrm{T}_{23}$ & 0.04 \\
\hline 11 & Accident rate per million vehicle kilometers $\mathrm{T}_{31}$ & 0.12 \\
\hline 12 & Speed limit $\mathrm{T}_{32}$ & 0.07 \\
\hline 13 & Emergency response time $\mathrm{T}_{33}$ & 0.01 \\
\hline 14 & Dangerous goods vehicle management $\mathrm{T}_{34}$ & 0.10 \\
\hline
\end{tabular}

The weight coefficient of the risk assessment index of the operation safety of the standard highway tunnel can also be determined according to the similar process.

After the calculated value, the safety risk level of tunnel operation is determined according to Table 5.

Table 5. Classification criteria for operation safety risk of tunnel

\begin{tabular}{|c|c|}
\hline Risk level & $\mathrm{R}$ \\
\hline Grade IV (very high risk) & $\mathrm{R}>80$ \\
\hline Level III (high risk) & $60<\mathrm{R} \leq 80$ \\
\hline Level II (moderate risk) & $40<\mathrm{R} \leq 60$ \\
\hline Grade I (low risk) & $\mathrm{R} \leq 40$ \\
\hline
\end{tabular}

\section{Conclusion}

With the rapid development of highway tunnel construction in China, the safety situation of highway tunnel operation is not optimistic, so it is very urgent to evaluate the safety of highway tunnel in service. Combined with the research status of safety evaluation of highway tunnels domestic and abroad, the safety checklist of highway tunnels is compiled by summarizing and analyzing the facility factors that affect the traffic safety of highway tunnels in China. Based on the concept of risk, the evaluation index system of tunnel operation safety risk is formed from three aspects: facility factor, environment factor and management factor. The evaluation index system of operation safety risk and the quantitative evaluation method of tunnel operation safety based on the index system method are proposed for the expressway and standard highway respectively, which is used to carry out the special safety evaluation of highway tunnel in service and provide technical support for the daily management and maintenance work and safety self inspection of the tunnel operation management unit.

\section{References}

1. Austroads. (2002) Road Safety Audit.

2. EuroTAP. (2007) Tunnel Audit Final Report.

3. Hou, Jingyu. (2015) Study on operation safety evaluation index system and evaluation method of the extra-long classified highway tunnel. Southwest Jiaotong University, Chengdu.

4. Gong, Hangjun, Wei, Xianwei. (2010) Study on comprehensive evaluation of operation safety of expressway tunnel. Journal of Highway and Transportation Research and Development, 27:51-59.

5. Wu, Hongbo, Zhou, Ronggui, Liao Junhong, Wang, Fang. (2012) Safety evaluation techniques for tunnel entrance sections on freeway. Journal of Highway 
and Transportation Research and Development, 29:126-132.

6. Zhang, Jingjing, Zhao Zhizhong. (2011) Research on Traffic safety assessment of expressway tunnel. Highway, 10:151-155.

7. Ma, Xiangxiang, Yu, Yuan, Zhang, Qingwu. (2016) Safety analysis on highway tunnel during operation based on STAMP model. Highway, 5:139-142.

8. Gu, Leiyu, Huang, Hongwei, Hu, Qunfang. (2007) Risk assessment on one sub-sea tunnel in its operational period. Chinese Journal of Underground Space and Engineering, 3:1236-1240. 